\title{
OPTIMALISASI PEMBERANTASAN KORUPSI DALAM ERA DESENTRALISASI DI INDONESIA
}

(Optimization of Eradication of Corruption in a Decentralized Era in Indonesia)

\author{
Suharyo \\ Pusat Penelitian dan Pengembangan Sistem Hukum Nasional \\ Badan Pembinaan Hukum Nasional \\ Jl. Mayjen Sutoyo Nomor 10 Cililitan Jakarta \\ Email: suharyo@bphn.go.id
}

Naskah diterima: 12 September 2014; revisi: 17 November 2014; disetujui: 28 November 2014

\begin{abstract}
Abstrak
Pelaksanaan desentralisasi merupakan kebijakan negara sebagai upaya mendekatkan pelayanan masyarakat dan kesejahteraan rakyat, menumbuhkan partisipasi masyarakat, serta good governance, ternyata berimplikasi negatif dengan menyuburnya korupsi di daerah. Untuk itu tulisan ini berusaha meneliti apa yang menyebabkan perilaku korupsi pada era desentralisasi serta bagaimana optimalisasi pemberantasan korupsi di tengah desentralisasi. Dengan menggunakan metode yuridis normatif disimpulkan bahwa penegak hukum di daerah tidak optimal dalam pemberantasan korupsi di wilayah hukumnya. Salah satunya adalah disebabkan keterbatasan jumlah penyidik KPK yang harus beroperasi di seluruh Indonesia. Perubahan Undang-Undang Nomor 32 Tahun 2004, yang diawali dengan diundangkannya Undang-Undang Nomor 6 Tahun 2014 tentang Desa, dan menyusul Perpu Nomor 1 Tahun 2014 tentang Pemilihan Gubernur, Bupati, dan Walikota, serta Undang-Undang Nomor 23 Tahun 2014 tentang Pemerintahan Daerah, dalam implementasinya diharapkan mampu mendinamisasikan serta meningkatkan derajat desentralisasi, dapat meminimalisir epidemi korupsi di daerah. Penguatan jajaran penegak hukum di daerah serta strategi represif merupakan upaya yang harus dikedepankan dalam optimalisasi pemberantasan korupsi.
\end{abstract}

Kata Kunci: desentralisasi, pengawasan, pemberantasan korupsi.

Abstract
The decentralization is a state policy to draw between public service and public welfare, emerging public participation and good governance, infact have negative implications for corruption at the local area increasingly. Therefore this paper try to examine what caused corruptive behaviour in the decentralization era as well as how to optimize corruption eradication in the decentralization era. Using normative juridis method, it can be concluded that the role of law enforcement officer in local area did not combat corruption within his jurisdiction optimally. It was caused by limited number of Corruption Eradication Commission's investigators which cover all areas in Indonesia. The amendment of Law number 32 year 2004, begins with the enactment of Law Number 6 year 2014 regarding Village and immediately followed by Government Regulations in lieu of Laws Number 1 year 2014 regarding Election of Governor, Regent and Major and also Law Number 23 year 2014 regarding Amandment of Local Government, it was expected to dynamize and develop decentralization in implementation could decrease corruption epidemic in local area. Strengthening of local law enforcement officers and also repressive strategy are prioritized in optimizing the eradication of corruption.

Keywords: decentralization, monitoring, corruption eradication. 


\section{A. Latar Belakang}

Epidemi korupsi, sebagai penyakit sosial, kejahatan yang sistemik, dan sangat merugikan rakyat, bangsa, dan negara, merupakan suatu fenomena yang sangat menyimpang pada semua negara di dunia. Untuk di Indonesia, korupsi yang ditengarai muncul beberapa tahun setelah Proklamasi Kemerdekaan Negara Kesatuan Republik Indonesia, terus menerus menunjukkan eksistensinya, walaupun secara terus menerus selalu diperangi. Pendekatan melalui penegakan hukum, dengan strategi represif, secara bervariasi selalu digelar oleh pemerintahan yang berkuasa. Dan setiap pergantian pemerintahan, utamanya sejak era reformasi yang diawali Pemerintahan Presiden BJ Habibie yang menggantikan Pemerintahan Presiden Soeharto, juga bertekad untuk memberantas korupsi.

Pada masa era reformasi, tuntutan rakyat untuk secara serius melakukan pemberantasan korupsi, kolusi, dan nepotisme (KKN) telah mendorong pemerintah upaya pemberantasan korupsi. Produk peraturan perundang-undangan, cukup cepat dibentuk untuk merubah dan menegaskan keseriusan memerangi korupsi. Kekhawatiran terhadap epidemi korupsi sangat beralasan. Korupsi, merupakan kejahatan sistemik yang sangat menular, dan mengakar dari lapisan terbawah di tengah masyarakat, sampai dengan melibatkan seluruh jajaran yang mempunyai kekuasaan, wewenang, dan kesempatan.

Era sentralisasi pada masa pemerintahan Presiden Soeharto, yang diwarnai otoritarian, berimplikasi meluas pada fenomena korupsi di tingkat pusat. Dengan berakhirnya era sentralisasi menuju era desentralisasi yang dimulai Pemerintahan Presiden BJ Habibie, yang melaksanakan Undang-Undang Nomor 22 Tahun 1999 Tentang Pemerintahan Daerah ${ }^{1}$, serta Undang-Undang Nomor 25 Tahun $1999^{2}$ Tentang Perimbangan Keuangan Pusat dan Daerah, penyebaran korupsi langsung merambah di daerah. Meluasnya korupsi di daerah, tidak berarti korupsi di tingkat Pusat menjadi terbatas atau sedikit. Namun korupsi di tingkat Pusat cenderung terbatas jika dibandingkan dengan kasus-kasus korupsi di Daerah.

Pergantian pemerintahan, silih berganti. Dari Presiden BJ Habibie kepada Pemerintahan KH Abdurrahman Wahid, Presiden Megawati Soekarnoputri, Presiden Soesilo Bambang Yudhoyono (2 kali periode masa jabatan). Penguatan organisasi penegakan hukum, mulai dari Kepolisian, Kejaksaan, dan Kekuasaan Kehakiman, serta peraturan perundangundangan tindak pidana korupsi (UndangUndang Nomor 31 Tahun $1999^{3}$ jo UndangUndang Nomor 20 Tahun $2001^{4}$ ) belum mampu mengefektifkan pemberantasan korupsi. Pembentukan Komisi Pemberantasan Korupsi 
(KPK) melalui Undang-Undang Nomor 30 Tahun 2002 tentang Komisi Pemberantasan Tindak Pidana Korupsi ${ }^{5}$, secara perlahan dan pasti mampu mengefektifkan pemberantasan korupsi.

Era sekarang, dengan tampilnya Pemerintahan Presiden Joko Widodo, strategi pemberantasan korupsi, dengan penguatan berbagai strategi dan keseriusan untuk menyelamatkan ekonomi nasional, keuangan negara, dan penguatan mentalitas bangsa Indonesia, segera dimulai.

Terdapat 2 (dua) dari 9 (sembilan) program dan agenda prioritas (Nawa cita) Joko WidodoJusuf Kalla, yaitu: ${ }^{6}$

Pada angka 4 memperkuat kehadiran negara dalam melakukan reformasi sistem dan penegakan hukum yang bebas korupsi, bermartabat, dan terpercaya.

Pada angka 8 melakukan revolusi karakter bangsa.

Desentralisasi dalam era reformasi yang biasa juga disebut Otonomi Daerah, diawali dari pemberlakuan Undang-Undang Nomor 22 Tahun 1999, sangat didukung oleh seluruh lapisan masyarakat di daerah. Perwujudan kesejahteraan, demokratisasi di tingkat lokal, pendekatan pelayanan, dan partisipasi warga masyarakat lokal dalam bingkai Negara Kesatuan Republik Indonesia (NKRI), merupakan harapan yang terkandung, dan semangat yang harus dijalankan di daerah. Namun eforia demokrasi yang juga menyebar ke daerah, yang telah mengakhiri pemerintahan Orde Baru yang sentralistik dan otoriter justru disambut secara negatif oleh elit politik (DPRD) dan jajaran birokrasi di daerah (Walikota/Bupati). Kalau pada masa lalu korupsi merupakan perilaku negatif dan melawan hukum oleh sementara aparatur pemerintah pusat, era otonomi daerah justru terjadi epidemi korupsi di daerah. Sehingga aspek menuju kesejahtaraan rakyat menjadi terabaikan. Hal ini juga disebabkan adanya raja-raja kecil Bupati/Walikota yang seringkali berkolusi dengan DPRD.

Revisi Undang-Undang Nomor 22 tahun 1999 menjadi Undang-Undang Nomor 32 Tahun 2004, ${ }^{7}$ serta revisi Undang-Undang Nomor 25 Tahun 1999 menjadi Undang-Undang Nomor 33 Tahun 2004,8 disamping adanya karena perubahan UUD 1945 juga memperhatikan Ketetapan MPR No. IV/MPR/RI Tahun 2000 tentang Rekomendasi Kebijakan Dalam Penyelenggaraan Otonomi daerah. Dan juga dengan memperhatikan kelemahan yang sangat mendasar, yang dapat memberi peluang korupsi pada jajaran DPRD dan Kepala Daerah.

Penerapan Undang-Undang Nomor 32 Tahun 2004, yang antara lain dimaksudkan untuk lebih mewujudkan good governance, sekaligus sebagai detterent factor terjadinya korupsi di daerah, ternyata masih dapat dibobol oleh pihak-pihak yang mempunyai peluang, niat, dan kesempatan untuk melakukan korupsi. Semua provinsi, kabupaten/kota tidak steril dari tindak pidana korupsi.

Lihat Undang-Undang Nomor 30 Tahun 2002 (Lembaran Negara Tahun 2002 Nomor 137, Tambahan Lembaran Negara Nomor 4250).

$6 \quad$ Kompas, Kerja Keras Jangan Berhenti di Pilpres, Sabtu 23 Agustus 2014.

7 Lihat Undang-Undang Nomor 32 Tahun 2004 (Lembaran Negara Tahun 2004 Nomor 125, Tambahan Lembaran Negara Nomor 4437).

8 Lihat Undang-Undang Nomor 33 Tahun 2004 (Lembaran Negara Tahun 2004 Nomor 126, Tambahan Lembaran Negara Nomor 4438). 
Setelah sempat menurun, praktik korupsi kembali marak dalam dua tahun terakhir. Kondisi tersebut menunjukkan kurang efektifnya pemberantasan korupsi, yang menyebabkan koruptor tak pernah jera dan selalu memiliki kesempatan untuk melakukan korupsi. Berdasarkan data yang dirilis Indonesian Corruption Watch (ICW), Minggu (17/8) jumlah kasus korupsi cenderung menurun selama 2010-1012, tetapi kembali meingkat pada 20132014. Pada 2010 jumlah kasus yang disidik Kejaksaan, Kepolisian dan KPK mencapai 448 kasus. Pada 2011, jumlahnya menurun menjadi 436 kasus dan menurun lagi pada 2012 menjadi 402 kasus. Namun pada 2013 jumlahnya naik signifikan menjadi 560 kasus. Pada 2014 jumlah kasus korupsi diperkirakan akan meningkat lagi mengingat selama semester I-2014 jumlahnya sudah mencapai 308 kasus. Sebagian besar tersangka adalah pejabat/pegawai pemerintah daerah dan kementerian yakni $42,6 \%$. Tersangka lain merupakan direktur/komisaris perusahaan swasta, anggota DPR/DPRD, kepala dinas, dan kepala daerah. ${ }^{9}$

Anatomi korupsi sangat dipengaruhi oleh dinamika, budaya hidup, pola hidup dan pengaruh lingkungan moral masyarakatnya, institusi sosial dan pranata-pranata sosial yang tumbuh dalam masyarakat. Proses klasifikasi dan identifikasi menunjukkan masalah korupsi telah menjadi fenomena sosial, serta dengan kajian sosiologi kriminal yang bersumber dari ilmi pengetahuan kriminologi, maka dapatlah dipahami tentang sebab musabab tipologi atau bentuk, jenis dan modus operandi korupsi yang menjadi semakin kompleks pada abad ke-21.10

Dalam rangka pelaksanaan kegiatan pemerintahan dan pembangunan, sesuai dengan teori administrasi/managemen, juga dibentuk institusi pengawasan seperti Inspektorat Jenderal, serta Inspektorat Wilayah, baik pada Pemda Provinsi maupun Kabupaten/ Kota. Namun ternyata, institusi pengawasan yang tercakup dalam struktur pemerintahan daerah, sampai sekarang belum terlihat di dalam menemukan korupsi di wilayahnya sendiri. Organ pengawasan tersebut, lebih bersifat penegakan disiplin di kalangan internal. Khusus dalam jajaran DPRD, memang tidak terdapat adanya lembaga pengawasan yang bisa mengawasi jajaran DPRD, hanya partai politik yang mengusung. Institusi pengawasan yang mampu mendeteksi korupsi baik di daerah maupun pusat, tidak lain Badan Pengawasan Keuangan dan Pembangunan (BPKP), dan Badan Pemeriksa Keuangan (Bepeka).

Berkenaan dengan dibentuknya Komisi Pemberantasan Korupsi (KPK), melalui Operasi Tangkap Tangan dan penyidikan lainnya, pada akhirnya pelaku-pelaku korupsi, termasuk dalam era desentralisasi dapat diproses, ditahan, dan diadili dalam Pengadilan Tindak Pidana Korupsi (Tipikor). Jajaran penegak hukum yang berada di daerah, yaitu Polri dan Kejaksaan, secara kualitatif dan kuantitatif, tidak optimal dalam pemberantasan korupsi. Dari uraian tersebut diatas, kompleksitas korupsi di tengah desentralisasi ekonomi, dapat diidentifikasi 
dua masalah penelitian, yaitu: pertama, apa yang menyebabkan perilaku korupsi pada era desentralisasi; serta kedua, bagaimana optimalisasi pemberantasan korupsi di tengah desentralisasi.

\section{B. Metode Penelitian}

Untuk menjawab dan menjelaskan permasalahan diatas, metode yang dipakai dalam penelitian ini adalah penelitian yuridis normatif, yang merupakan penelitian kepustakaan (library research), yaitu melalui pengumpulan data kepustakaan. Pendekatan normatif sangat relevan guna menganalisis peraturan perundang-undangan yang berlaku dalam pemberantasan korupsi, kebijakan terbaru, serta semangat dan tekad yang dicanangkan dalam program, dan agenda prioritas yang disebar luaskan kepada seluruh masyarakat Indonesia dalam era desentralisasi, utamanya dalam pemerintahan sekarang ini.

\section{Pembahasan}

\section{Korupsi Era Desentralisasi}

Desentralisasi menurut Mark Turner ${ }^{11}$ merupakan salah satu konsep di dalam ilmu sosial yang memiliki banyak makna disepanjang waktu. Pemaknaan yang beragam ini tidak lepas dari banyaknya aplikasi disiplin dan perspektif di dalam ilmu sosial yang concern terhadap studi mengenai desentralisasi. Menurut Litvark \& Seddon ${ }^{12}$, arti desentralisasi adalah "the transfer of authority and responsibility of public function from central government to subordinate or quasi independent government organization or the private sector" (transfer kewenangan dan tanggung jawab fungsi-fungsi publik, transfer ini dilakukan dari pemerintah pusat kepada pihak lain, baik kepada daerah bawahan, organisasi pemerintah yang semi bebas ataupun kepada sektor swasta).

Adapun menurut pasal 1 ayat (7) UndangUndang Nomor 32 Tahun 2004, desentralisasi adalah penyerahan wewenang pemerintahan oleh Pemerintah kepada Daerah Otonomi untuk mengatur dan mengurus urusan pemerintahan dalam sistem Negara Kesaturan Republik Indonesia. Disamping itu, dalam pasal 1 ayat (5), otonomi daerah adalah hak, wewenang dan kewajiban daerah otonomi untuk mengatur dan mengurus sendiri urusan pemerintah dan kepentingan masyarakat setempat sesuai dengan peraturan perundang-undangan.

Sedangkan hal tentang Korupsi ${ }^{13}$, seperti halnya dengan semua gejala sosial yang rumit, korupsi tidak dapat dirumuskan dalam satu kalimat saja, yang mungkin ialah membuat gambaran yang masuk akal mengenai gejala tersebut agar kita dapat memisahkannya dari gejala lain yang bukan korupsi. Korupsi adalah penyalahgunaan kepercayaan untuk kepentingan pribadi.

Tindak kejahatan yang dilakukan dengan menggunakan hukum sebagai alatnya dinamakan kejahatan sempurna (perfect crime). Dikatakan sempurna karena tindakan itu sengaja dibungkus dengan hukum yang berlaku, sehingga seolah-olah merupakan bagian dari penegakan hukum atau kebijakan resmi.

Kacung Marijan, Sistem Politik Indonesia, Konsolidasi Demokrasi Pasca Orde Baru, (Jakarta; Kencana Preneda Media Group, 2010), hlm.138.

12 Sadjijono, Fungsi Kepolisian Dalam Pelaksanaan Good Governance, (Yogyakarta; Laksbang, 2010), hlm. 278.

13 Syed Hussen Alatas, Korupsi Sebab, Sifat, dan Fungsi, (Jakarta; LP3ES 1987), hlm. 45 
Artinya, apa yang senyatanya jahat tersembunyi dalam tindakan yang sah, seperti keputusan politik, keputusan tata usaha negara, keputusan kebijakan publik, pengumuman kemenangan tender proyek, promosi media massa, kebijakan dalam penyidikan, strategi penuntutan dan/ atau putusan pengadilan, sehingga seolah-olah tidak ada kejahatan. ${ }^{14}$

Terdapat beberapa definisi tentang korupsi, yaitu: ${ }^{15}$ pertama, discretionary corruption, korupsi yang dilakukan karena adanya kebebasan dalam menentukan kebijaksanaan, sekalipun nampaknya bersifat sah. Kedua, ellegal corruption, adalah suatu jenis tindakan yang bermaksud mengacaukan bahasa ataupun maksud-maksud hukum, peraturan dan regulasi tertentu. Dalam hal terjadi aksi-aksi seperti ini, risiko yang akan terjadi cukup implisit. Ketiga, mercenery corruption, adalah suatu jenis tindak korupsi yang dimaksud untuk memperoleh keuntungan pribadi. Ia meliputi kegiatan pemberian uang sogok dan uang semir. Keempat, ideological corruption atau korupsi ideologis adalah jenis korupsi yang bersifat ilegal maupun diskresionari yang dimaksudkan untuk mengejar tujuan-tujuan kelompok.

Eksistensidan penerapan pemerintahanyang mengedepankan demokrasi serta supremasi hukum, akan mendekatkan pada pelaksanaan desentralisasi. menurut Van der Walle ${ }^{16}$ hal-hal sebagai akibat positif desentralisasi adalah:

a. Pastisipasi masyarakat sipil dapat diperluas dalam aspek-aspek politik, ekonomi, dan

sosial yang pada gilirannya akan semakin memperkuat proses demokrasi;

b. Pelayanan publik dapat dilakukan secara lebih efisien dan efektif;

c. Sektor publik (pemerintah dan swasta) dipaksa menjadi lebih akuntabel/ bertanggung jawab, karena harus transparan dalam bekerja dan lebih responsif terhadap kebutuhan dan tuntutan masyarakat;

d. Dalam kaitannya dengan isu pengentasan kemiskinan dan hak-hak daerah dan kelompok-kelompok masyarakat yang termarginalkan, desentralisasi diharapkan akan memungkinkan suara mereka lebih didengar secara substansial, karena akses mereka ke pembuatan keputusan politik lebih besar.

Desentralisasi di Indonesia merupakan bentuk dari demokrasi politik dan demokrasi ekonomi,yaitupenyerahandanpenyelenggaraan pemerintah pusat kepada pemerintah daerah melalui kewenangan tertentu. Demokrasi politik yang diserahkan yaitu urusan pemilihan kepala daerah secara langsung, umum, bebas, rahasia, jujur dan adil. Demokrasi ekonomi disamping memberikan keleluasaan pada daerah untuk mengelola dan mengatur berbagai jenis pajak, juga mempunyai hak dan wewenang untuk mencari Pendapatan Asli Daerah (PAD) demi kesejahteraan dan kepentingan masyarakat, namun tetap dalam kerangka sesuai peraturan perundang-undangan yang ada.

Implementasi desentralisasi dalam aspek kesejahteraan rakyat tidak lain menuju pada 
pertumbuhan ekonomi dan pemerataan. Menurut Robert A. Simanjuntak ${ }^{17}$, agar pertumbuhan ekonomi dan pemerataan (pengurangan kesenjangan) antar daerah tercapai, pemerintah daerah harus mengetahui berbagai potensi yang dimiliki di daerahnya dan daerah sekitarnya, yang secara langsung atau tidak langsung berhubungan dengan pembangunan di daerahnya. Selain itu penyusunan program pembangunan satu daerah harus memperhatikan kesinergian hubungan dengan pembangunan daerah lainnya. Dalam upaya mencapai efisiensi, pemerintah daerah harus membantu penyediaan fasilitas produksi dan memprioritaskan alokasi anggaran secara tepat pada sektor-sektor yang potensial. Bila hal-hal tersebut tidak dilakukan penerapan program otonomi daerah dapat menjadi sebuah kebijakan kontra produktif dan bahkan berdampak negatif berupa pelebaran tingkat kesenjangan terjadinya ekonomi biaya tinggi. Apabila kebijakan tersebut kontra produktif, maka yang seharusnya dilakukan adalah peninjauan, pembatalan kebijakan untuk menghindari pemborosan dana dan hal-hal lain yang tidak diinginkan yang mungkin terjadi atau reformulasi yang memungkinkan pelaksanaan.

Ditinjau dari aspek ekonomi, menurut Nuralam $^{18}$ perubahan yang utama dalam pelaksanaan desentralisasi terletak pada perspektif bahwa sumber-sumber ekonomi yang tersedia di daerah harus dikelola secara mandiri dan bertanggung jawab dan hasilnya lebih diorientasikan pada peningkatan kesejahteraan dan pelayanan kepada masyarakat di daerah. Tugas pengelolaan merupakan mandat masyarakat di daerah yang menjadi kewajiban bagi manajemen pemerintahan di daerah untuk melaksanakannya. Pelaksanaan otonomi daerah dan desentralisasi fiskal memberikan peluang yang lebih besar kepada pemerintah daerah untuk mengembangkan dan membangun daerahnya sesuai dengan kebutuhan dan prioritas masing-masing, sehingga pelaksanaan pembangunan daerah diharapkan lebih berorientasi pada kebutuhan daerah setempat sesuai dengan skala prioritasnya masing-masing.

Politik hukum desentralisasi yang antaranya untuk mewujudkan kesejahteraan ekonomi rakyat seharusnya berjalan paralel. Menurut Dindin S. Damanhuri ${ }^{19}$, setidaknya ada empat kategori di dunia dalam hubungan antara demokrasi politik dan kesejahteraan ekonomi rakyat.

Pertama, bersamaan dengan sukses demokrasi politik juga diikuti oleh tingkat kesejahteraan ekonomi rakyat yang signifikan sepertidipertontonkanolehnegara-negaraBarat. Meski harus diberi catatan bahwa kemakmuran mereka tak lepas dari politik kolonialisme dan imperialisme terhadap negara berkembang di masa lalu disamping standar ganda yang tak demokratis di tingkat hubugan internasional vis à vis negara berkembang sekarang ini. Di luar negara-negara Barat tersebut, juga terdapat Jepang, Turki, dan negara-negara industri baru

17 Robert A. Simanjuntak et.all, Pasang Surut Otonomi Daerah Sketsa Perjalanan 100 Tahun (Jakarta; TIFA \& Institute In Local Development 2005), hlm. 311.

18 Nuralam, Kesejahteraan Yang Tersandra Implementasi Desentralisasi Fiskal dan Otonomi Khusus di Papua, (Yogyakarta; Sarjana 2011), hlm. 262-263.

19 Dindin S. Damanhuri, Korupsi, Reformasi Birokrasi dan Masa Depan Ekonomi Indonesia, (Jakarta; Lembaga Penerbit Fakultas Ekonomi Universitas Indonesia 2006), hlm. 84-85. 
Asia (Korea, Malaysia, dan Thailand). Kedua, negara-negara yang tak demokratis secara politik namun tingkat kesejahteraan ekonomi rakyatnya relatif tinggi dan merata seperti diperlihatkan di China dan Singapura. Ketiga, negara-negara yang tradisi demokrasi politiknya maju namun kesejahteraan ekonomi sebagian besar rakyatnya rendah, seperti dicontohkan India dan Philipina, serta banyak negara-negara Amerika Latin. Keempat, negara yang demokrasi politik dan kesejahteraan ekonomi rakyatnya buruk dan rendah seperti yang terjasdi di Pakistan, Bangladesh, dan hampir semua negara-negara Afrika.

Mewabahnya korupsi di tengah desentralisasi paling tidak dapat terjadi karena berbagai faktor, yaitu: pertama, pola hidup mewah yang mengagungkan nilainilai kebendaan tanpa pengendalian diri yang kuat, merupakan langkah awal untuk terjebak melakukan korupsi. Kedua, terjadi pengelolaan keuangan dari berbagai kegiatan yang semula dikelola langsung oleh pemerintah pusat, diserahkan kepada daerah, sehingga menimbulkan semangat untuk melakukan penyimpangan. Ketiga, era desentralisasi yang didalamnya diwarnai berbagai gejolak, dianggap oleh pihak-pihak yang berorientasi penyimpangan pengelolaan keuangan sebagai peluang untuk melakukan manipulasi dan korupsi. Keempat, pengawasan dari pemerintah pusat lemah; sementara unsur pengawasan di daerah disamping tidak berfungsi justru sering melakukan kolusi. Kelima, dalam Pemilihan Kepala Daerah (Pemilukada), sangat diperlukan dana yang sangat besar; sementara gaji dan pendapatan resmi kepala daerah jika terpilih dan dipilih selama masa jabatan tidak sebanding dengan pengeluaran yang ada. Sehingga mereka mencoba-coba untuk melakukan korupsi di daerahnya. Keenam, jajaran penegak hukum di daerah yaitu Polri dan Kejaksaan cenderung menghindari penyelidikan dan penyidikan kasus-kasus korupsi yang melibatkan petinggi di daerah.

Otonomi Daerah sejatinya berpotensi untuk menyebarluaskan terjadinya korupsi. Hal ini terjadi apabila kewenangan dan keuangan yang sudah diserahkan oleh pemerintah pusat kepada pemerintahan daerah tidak diawasi penggunaannya. Hal ini telah terjadi di Indonesia, baik secara normatif maupun secara praktik. Dana dekosentrasi dan dana tugas pembantuan adalah dua jenis dana yang diberikan oleh pusat ke daerah dan sangat sulit untuk diawasi penggunaannya. Oleh sebab itu, temuan KPK sangat mungkin benar adanya. Dana-dana dekonsentrasi adalah dana yang dimiliki dan dianggarkan oleh sektor-sektor di tingkat pusat untuk pembangunan daerah. ${ }^{20}$

Korelasi antara pemberantasan korupsi dengan era desentralisasi, terlihat sulit untuk terbantahkan. Semua daerah termasuk daerah pemekaran, baik dari provinsi serta kabupaten/ kota, juga terjadi korupsi. Strategi Preventif dan represif dalam skala terbatas, diwarnai berbagai kegagalan. Dari beberapa penelusuran data, dapat disimpulkan. Pada 2010, Provinsi Sumatera Utara dalam provinsi terkorup menurut catatan Indonesian Corruption Watch (ICW). Pada 2012, posisinya tak banyak berubah. Data yang dilansir Forum Indonesia untuk Transparansi Anggaran (FITRA) menyebutkan, Sumatera Utara menempati posisi ketiga provinsi

20 Eko Prasodjo, Reformasi Kedua Melanjutkan Estafet Reformasi (Jakarta; Salemba Humanika 2009), hlm. 180. 
terkorup di Indonesia. Data FITRA berdasarkan hasil pemeriksaan Badan Pemeriksa Keuangan (Bepeka) pada Semester II Tahun 2011. Provinsi terkorup ditempati Provinsi DKI jakarta, dengan kerugian negara sebesar Rp.721,5 miliar (715 kasus). Provinsi Nangro Aceh Darussalam ranking kedua dengan kerugian negara sebesar Rp.669,8 miliar (629 kasus). Provinsi Sumatera Utara sebesar Rp.515,2 miliar dengan jumlah kasus sebanyak 334 kasus. ${ }^{21}$

Dalam kurun sepekan ${ }^{22}$ tiga kepala daerah dijadikan tersangka dalam kasus korupsi, dua diantaranya ditangani KPK, sedangkan lainnya oleh Polda Papua. Menambah panjang daftar kepala daerah yang terjerat kasus korupsi. Berbagai kasus korupsi yang menimpa kepala daerah semakin memperkuat dugaan kalau mereka telah menjadi raja lalim di daerahnya. Keberadaan Komisi Pemberantasan Korupsi (KPK) pun semakin dibutuhkan. Yang membuat miris adalah penetapan tersangka terhadap mantan Walikota Makassar Ilham Arief Sirajudin dan Bupati Bogor Rahmat Yasin. Sirajudin ditetapkan sebagai tersangka. Menyusul kemudian Bupati Mybart Bernard Siagian, ditetapkan Polda Papua sebagai tersangka kasus korupsi senilai Rp.3 miliar.

Pengadilan Tipikor menorehkan sejarah baru dengan menjatuhkan hukuman seumur hidup kepada Akil Muchtar. KPK pun siap membidik 15 kepala daerah yang menyuap mantan Ketua MK itu. Langkah KPK diawali dengan menetapkan Walikota Palembang Romi Herton sebagai tersangka. Dari 15 perkara yang ditangani Akil Mochtar, beberapa perkara sudah divonis seperti suap Pilkada Gunungmas yang melibatkan Bupati Hambit Bintih. Pilkada Lebak persidangannya masih berjalan di Pengadilan Tipikor Jakarta. Bupati Lebak Amir Hamzah dan Wakil Bupati Kosmin statusnya juga sudah dicekal. Yang teranyar, KPK sudah menetapkan Walikota Palembang Romi Herton dan isterinya, Masitoh sebagai tersangka. Selain itu, masih ada Pilkada Kabupaten Buton, Empat Lawang, Pulau Murotai, Tapanuli Tengah, Provinsi Jawa Timur, Kabupaten Boven Digoel, Kabupaten Asmat, Kabupaten Merauke, Kota Jayapura, Kabupaten Nduga, Provinsi Banten, yang belum disentuh. ${ }^{23}$

KPK berkeyakinan operasi tangkap tangan dalam kasus Bupati Karawang terkait bargaining pemberian izin yang berujung pemerasan. Kasus yang menyeret Bupati Karawang dan isterinya itu, terkait dugaan korupsi pemerasan dalam penerbitan Surat Pernyataan Pengelolaan Lingkungan Hidup (SPPL) untuk PT Tatar Kertabumi. Informasi yang berbeda di kalangan wartawan, PT Tatar kertabumi merupakan anak perusahaan PT Agung Podomoro Land (APLN). Diketahui PT Tatar Kertabumi baru saja diakuisisi APLN melalui PT Pesona Gerbang Karawang senilai Rp.61 miliar. Perusahaan tersebut berencana membangun superblock mini di Kabupaten Karawang dengan lahan 5,5 hektar. ${ }^{24}$

Kasus korupsi yang membelit Rina Iriani Sri Ratnaningsih, mantan Bupati Karanganyar dua periode 2003-2008, dan 2008-2013 yang semula berjalan lamban, kini memasuki babak baru.

21 Noname,"Dua Cari Kuasa, Tiga Haus Kuasa”, Forum Keadilan No.43/25 Februari - 03 Maret 2013.

22 Noname, "Lolos di Lahan Kuburan Terjerat di Hutan", Forum Keadilan No.03 Tahun XXIII/12-18 Mei 2014.

23 Noname, "Akil divonis, KPK Bidik 15 Kepala Daerah", Forum Keadilan No.11, Tahun XXIII/07-13 Juli 2014.

24 Noname, "Agung Podomoro Tersangkut Bupati Karawang?", Forum Keadilan No.14 Tahun XXIII/11-17 Agustus 2014. 
Berbagai manuverpun sempat mengemuka dalam kasus ini. Apalagi Rina disebut-sebut mempunyai pengaruh kuat di Jawa Tengah, baik secara politis maupun materi. Buktinya, sejak ditetapkan sebagai tersangka oleh Kejati Jawa Tengah, November tahun lalu, Rina tak kunjung di tahan. Alhasil sidang pertamapun menjadi terlambat. Kondisi ini sangat mendapat sorotan dari Komisi Yudisial Penghubung KY Jawa Tengah. Syukron Salam menyatakan persidangan molor sampai satu jam lebih hanya karena menunggu kedatangan Rina Iriani dari Karanganyar. Padahal; majelis hakim, jaksa penuntut umum dan penasehat hukum sudah datang. ${ }^{25}$

Dari berbagai kasus korupsi di tengah desentralisasi, pengelolaan dana Bantuan Sosial menjadi ajang dijadikan alat korupsi. Dengan cakap membuat proposal atas nama organisasi massa, lembaga swadaya masyarakat, lembaga pendidikan, lembaga keagamaan, baik yang dibentuk secara fiktif maupun melalui pemotongan-pemotongan dana tersebut dapat langsung dicairkan. Fungsi pengawasan dari DPRD sangat lemah. Paling tidak terdapat beberapa Gubernur dalam era desentralisasi yang terlibat dalam korupsi, dimulai dari Abdullah Puteh (Gubernur Aceh), Syamsul Arifin (Gubernur Sumatera Utara), Djoko Munandar dan Atut Chosiah (Gubernur Banten) telah menjalani pemidanaan. Belum lagi beberapa Gubernur yang menjadi tersangka. Ratusan Bupati, Walikota, dan lebih dari seribu anggota DPRD yang menjadi terpidana. Korelasi desentralisasi korupsi selain melibatkan jajaran pejabat negara dan DPRD, diantaranya juga melibatkan pihaklain. Fenomena ini berlangsung sejak Undang-Undang Nomor 22 Tahun 1999, dan setelah diganti menjadi Undang-Undang Nomor 32 Tahun 2004, ternyata korupsi di daerah tidak berhenti secara total.

Adapun modus operandi kejahatan korupsi di daerah, menurut Luthfi Kurniawan ${ }^{26}$, modus korupsi aktual kerjasama antara sektor publik dengan personal privat:

a. Penipuan terhadap anggaran dengan mengambil pos anggaran lain dengan maksud menyembunyikan nama pos yang mungkin dianggap terlalu mencolok atau mengada-ada;

b. Menciptakan anggaran baru yang sebenarnya tidak diatur dalam peraturan;

c. Mark Up anggaran dengan melebihkan berbagai tunjangan (anggota dewan) yang telah diatur dalam Undang-Undang;

d. Pengalokasian anggaran yang sebetulnya sama dengan anggaran lainnya (duplikasi anggaran);

e. Pembuatan anggaran tanpa perincian. Modus ini dilakukan dengan cara membuat anggaran dalam bentuk satuan tanpa diperinci lagi;

f. Menghilangkan pos anggaran;

g. Pengalihan anggaran yang seharusnya diberikan dalam bentuk jaminan asuransi menjadi dalam bentuk uang;

h. Bantuan berbentuk uang diubah barang dan mengurangi spesifikasinya;

Noname, "Pundi-pundi Keluarga Rina Berisi Uang Haram. KY Minta Rina Ditahan”. Forum Keadilan No.16 Tahun XXIII/25-31 Agustus 2014.

26 Luthfi Kurniawan et all, Peta Korupsi Politik di Daerah, (Malang; Malang Corruption Watcht (WCW dan Yupika Jakarta 2006), hlm. 75. 
i. Pengadaan barang dan jasa dengan cara di mark up harga barang dan jasa dari harga pasar dan kolusi dengan kontraktor;

j. Penghapusan barang inventaris dan asset negara dengan cara memboyong inventaris kantor untuk kepentingan pribadi;

k. Pemotongan bantuan sosial atau subsidi (sekolah, panti asuhan, pesantren, dan lainlain) melalui cara dengan menyunat dana bantuan yang dilakukan di tiap tingkatan meja.

I. Penyelewengan dana proyek dengan cara mengambil dana proyek diluar ketentuan dan memotong dana proyek;

m. Proyek fisik fiktif dalam laporan tercantum tetapi di lapangan nihil tidak ada proyek.

n. Pungli penerimaam CPNS, pembayaran gaji, kenaikan pangkat, pengurusan pensiun dengan cara memungut biaya tambahan diluar ketentuan resmi;

o. Manipulasi hasil penerimaan penjualan penerimaan pajak, retribusi dan iuran dari jumlah riil penerimaan pajak tidak dilaporkan serta penetapan target penerimaan pajak lebih rendah dari penerimaan riil;

p. Manipulasi proyek fisik (jalan, jembatan, bangunan kantor, sekolah, asrama) dengan cara mark up nilai proyek, pungutan komisi tidak resmi.

Dengan pemekaran daerah, yang dimaksudkan untuk mendekatkan pelayanan kepada warga, masyarakat serta mewujudkan kesejahteraan rakyat, ternyata juga menjadi peluang untuk melakukan korupsi. Fenomena korupsi terbentuknya daerah pemekaran, juga melibatkan anggota DPR, aparat pemerintah pusat, juga para penghubung (calo). Dan setelah terbentuknya daerah pemekaran, melalui berbagai penggelontoran dana untuk pembangunan perkantoran, pembelian ATK, pembelian kendaraan dinas, sampai pengisian jabatan, ditengarai terjadi korupsi.

Menurut Tri Ratnawati ${ }^{27}$, pada tahun 2006 diperkirakan sekitar 250 triliun rupiah atau kira-kira 20\% dari Produk Domestik Bruto (PDB) telah dialihkan dari Pusat ke Daerah-daerah pemekaran. Peningkatan pengeluaran negara tersebut terjadi karena setiap pembentukian daerah baru memerlukan kantor polisi baru, kantor agama baru, kantor pengadilan baru, penambahan pegawai baru, dan lain-lain. Hasil audit yang dilakukan BPK pada tahun 2007 menyimpulkan mengenai buruknya kinerja keuangan daerah-daerah pemakaran. Selain mengandalkan dana dari Pusat, daerah baru hasil pemekaran juga kekurangan SDM aparatur pemerintah. Menurut salah satu auditor di BPK, sekitar 83 persen dari 148 daerah hasil pemekaran, kondisi keuangan daerahnya tidak memenuhi syarat.

Kejahatan korupsi telah menyengsarakan rakyat, merugikan negara dan menghancurkan kepercayaan rakyat terhadap negaranya. Fenomena korupsi di Indonesia semakin meningkat, baik secara kuantitas maupun kualitas. Semua institusi pemerintahan telah ditemukan kasus korupsi. Bahkan di daerah, dalam pelaksanaan desentralisasi korupsi seakan tidak berhenti.

Desentralisasi yang digelar di Indonesia dalam era demokrasi, diantaranya bertujuan untuk memakmurkan rakyat di daerah, penegakan

Tri Ratnawati, Pemekaran Daerah, Politik Lokal \& Beberapa Isu Terseleksi, (Yogyakarta; Pustaka Pelajar 2009), hlm. 21. 
supremasi hukum, pendekatan pelayanan kepada masyarakat, dan membangkitkan partisipasi rakyat, ternyata dalam prakteknya ditemui penodaan dan pengingkaran terhadap kepentingan rakyat.

Korupsi sebagai penyalahgunaan untuk kepentingan pribadi, menjadi model perilaku menyimpang di tengah desentralisasi. Seolaholah korupsi di dalam desentralisasi akan berlomba dengan korupsi yang terjadi di dalam jajaran pemerintahan pusat.

\section{Optimalisasi Pemberantasan Korupsi Di Era Desentralisasi.}

Korupsi di tengah desentralisasi, sangat menciderai semangat dan tujuan desentralisasi di Indonesia. Penyelengaraan pemerintahan di daerah, yang dilandasi prinsip demokrasi, good governance, semangat dan pengendalian diri yang kuat merupakan pilihan terbaik. Penguatan jajaran penegak hukum di daerah utamanya Kepolisian dan Kejaksaan agar serius, berani, dan konsisten dalam memberantas korupsiperlu dibudayakan. Dan khusus sebagai detterend factor terjadinya korupsi, sanksi hukum pidana harus dimaksimalkan, pengembalian harta dari hasil korupsi, serta dicabut hak politik seumur hidup. Hal senada dikatakan R.D. Schwartz and S. Orleans ${ }^{28}$ yang mengatakan bahwa sanksi negatif (cq hukuman) mengurangi pelanggaran, baik yang dilakukan oleh pelanggar maupun pihak-pihak lainnya; semakin keras sanksi negatif, semakin tinggi derajat efektivitasnya; sanksi negatif dapat diterapkan tanpa mengakibatkan terjadinya kerugian-kerugian; serta kemungkinan-kemungkinan lain tidak dapat dianggap sebagai suatu alternatif yang sederajat dengan penerapan sanksi negatif.

Desentralisasi merupakan kewajiban dan tanggung jawab negara, agar terus dilaksanakan untuk kepentingan rakyat, dalam konteks Negara Kesatuan Republik Indoesia (NKRI). Di dalam negara hukum yang demokratis, sesungguhnya desentralisasi harus lebih berhasil di dalam menyejahterakan rakyat. Peranan warga masyarakat dalam era desentralisasi yang sekaligus mencegah perilaku menyimpang korupsi, perlu ditumbuhkembangkan.

Penegakan hukum, merupakan langkah terakhir dalam pemberantasan tindak pidana korupsi. Ancaman, gangguan, hambatan, dan tantangan (AGHT), serta peluang dan kesempatan untuk melakukan korupsi utamanya di daerah justru lebih besar. Aspek liberalisasi ekonomi, yang memunculkan barang-barang mewah di pasaran sudah lama merambah di seluruh wilayah tanah air. Mobil mewah, rumah mewah beserta perlengkapannya, dan gaya hidup mewah yang selama puluhan tahun terakhir ini bermunculan di media informatika merupakan demonstration effect yang sangat kuat oleh pihak-pihak yang tidak mampu mengendalikan diri. Pembangunan ekonomi, usaha pertambangan, perkebunan, perumahan, industri, pertanian menjangkau seluruh kawasan strategis untuk berinvestasi. Disini pengendalian diri yang kuat dari pejabat di daerah, dari Bupati, Walikota, DPRD bahkan ada yang sampai di tingkat Provinsi, seringkali tidak mampu menahan diri dari godaan uang dalam jumlah yang besar.

Berkenaan untuk menjadi Bupati, Walikota, Anggota/Ketua DPRD sampai Gubernur 
memerlukan modal yang sangat besar, maka izin untuk melakukan investasi dari para pihak, merupakan peluang luas untuk untuk menutup pengeluaran dalam pencalonannya. Belum lagi kalau memang dari hati nuraninya belum menjadi pejabat berkeinginan memperoleh keuntungan yang besar dalam masa jabatannya. Ongkos untuk menjadi Calon Bupati, Walikota, Gubernur menjadi sangat besar karena yang bersangkutan harus memperoleh persetujuan dari partai politik secara berjenjang dari daerah sampai dengan dewan pimpinan pusat partai pengusungnya.

Fungsi pengawasan di daerah dari lembaga perwakilan daerah (DPRD) tidak efektif. bahkan justru lebih banyak melakukan kolusi. Inspektorat Wilayah lebih bersifat pembinaan dan pengawasan terhadap birokrasi di daerah. Unsur penegakan hukum di daerah utamanya Polrij $^{29}$ dan Kejaksaan ${ }^{30}$ juga tidak berdaya, dalam banyak hal cenderung membiarkan. Pada akhirnya, penyelesaian dan penanganan korupsi di daerah juga dilakukan oleh KPK. Paling tidak, warga masyarakat tidak terlalu kaget dengan keberhasilan operasi tangkap tangan oleh KPK terhadap Bupati Bogor dan berikutnya Bupati Karawang beserta isterinya, beberapa bulan yang lalu.

Sebagaimana diketahui bersama, bahwa KPK merupakan lembaga yang bersifat ad hoc atau sementara di dalam melaksanakan fungsi pemberantasan korupsi. Pembuatan/ pembentukan KPK berdasarkan alasan yang sangat kuat, bahwa penegak hukum Polri, dan Kejaksaan tidak berdaya dalam pemberantasan korupsi. Dalam aspek peraturan perundangundangan, KPK tidak menemui kendala yang berarti. Undang-Undang yang ada sangat efektif untuk melakukan tindakan memberantas korupsi. Walaupun dalam penerapan UndangUndang Nomor 8 Tahun 2010 tentang Tindak Pidana Pencucian Uang ${ }^{31}$, KPK beberapa kali dipersalahkan yang menyatakan KPK tidak berhak menuntut TPPU, terakhir oleh Kuasa Hukum Akil Muchtar Tamsil Sjoekoer. ${ }^{32}$

Keterbatasan jumlah sumber daya manusia pada penyidik KPK, yang selalu mengandalkan peran, kerjasama dan bantuan baik dari Kepolisian, Kejaksaan maupun BPKP merupakan kendala serius yang selalu menghambat kecepatan penyidikan dan penentuan dari KPK. Dalam waktu 2 tahun mendatang, memang sarana dan prasarana berupa gedung Kantor KPK diharapkan selesai dibangun dan bisa dipakai. Namun persoalan sumber daya manusia yang terbatas, perlu diantisipasi sejak awal masih tergantung dalam ingatan kita ketika Joko Widodo mengatakan "Anggaran KPK akan ditingkatkan 10 kali lipat" di gedung KPK 26 Juni lalu, pada saat klarifikasi kekayaannya. Korupsi di Indonesia memang sungguh memprihatinkan. Sejak KPK berdiri 10 tahun yang lalu, pengaduan yang masuk sebanyak 69.773 kasus, tetapi yang

29 Lihat Undang-Undang Nomor 2 Tahun 2002 (Lembaran Negara Tahun 2002 Nomor 2, Tambahan Lembaran Negara Nomor 4168).

30 Lihat Undang-Undang Nomor 16 Tahun 2004 (Lembaran Negara Tahun 2004 Nomor 67, Tambahan Lembaran Negara Nomor 4401.

31 Lihat Undang-Undang Nomor 8 Tahun 2010 (Lembaran Negara Tahun 2010 Nomor 122, Tambahan Lembaran Negara Nomor 5164).

32 KPK Tak Berhak Menuntut TPPU. Furom Keadilan No.15 Tahun XIII/18-24 Agustus 2014. 
ditangani langsung oleh KPK tidak sampai 500 kasus. $^{33}$

Kendala implementasi pemberantasan korupsi dalam desentralisasi maupun aspek ketidak seriusan pihak-pihak terkait, harus dikembalikan pada tugas negara. Secara spesifik tugas negara: ${ }^{34}$

a. Negara harus memberikan perlindungan kepada para penduduk dalam wilayah tertentu, perlindungan terhadap ancaman dari luar negeri dan dalam negeri, perlindungan terhadap ancaman penyakit atau terhadap bahaya-bahaya lalu lintas;

b. Negara mendukung atau langsung menyediakan pelbagai pelayanan kehidupan masyarakat dalam bidang sosial, ekonomi, dan kebudayaan;

c. Negara menjadi wasit yang tidak memihak antara pihak-pihak yang berkonflik dalam masyarakat serta menyediakan suatu sistem yudisial yang menjamin keadilan, dasar dalam hubungan sosial masyarakat.

Partisipasi rakyat dalam melaporkan kasus korupsi di daerahnya sesungguhnya sangat positif, namun mengandung resiko yang tinggi. Warga masyarakat dan kalangan yang mengerti hukum, dipastikan merespon kasus-kasus korupsi di daerahnya. Sebagai fenomena umum, informasi dan laporan kepada Polri dan/atau Kejaksaan setempat, tidak seluruhnya direspon. Bahkan bisa jadi, warga masyarakat tersebut diperiksa Polri melalui pencemaran nama baik. Yang lebih harus diwaspadai oleh pihak-pihak pelapor tindak pidana korupsi, adalah adanya kemungkinan kekerasan dan pembunuhan dari pihak-pihak yang tidak dapat diketahui identitasnya.

Bersamaan dengan hal itu optimalisasi pemberantasan korupsi di Indonesia dalam konteks era desentralisasi merupkan kebutuhan mutlak dan mendasar. Utamanya para penegak hukum di daerah harus dibangkitkan untuk secara serius konsisten, berani, tegas, dan adil dalam memerangi korupsi di wilayah hukumnya. Dan unsur pimpinan di pusat, harus mendukung secara konsisten dan konsekuen.

\section{Penutup}

Banyak faktor yang melatarbelakangi terjadinya korupsi, dalam era desentralisasi korupsi seolah-olah menyatu dalam penyelenggaraan pemerintahan daerah. Pola hidup mewah, mengagungkan nilai-nilai kebendaan, mengebiri dan memanipulasi pelaksanaan peraturan perundang-undangan, mereduksi etika moral, nafsu untuk menduduki jabatan, pengawasan yang lemah, dan penegakan hukum yang tidak konsisten serta memihak, menjadi tempat yang subur dan berkembangnya korupsi. Perilaku koruptif dalam aspek moral dan etika menunjukkan suatu kelemahan dan penyimpangan sosial. Dalam aspek sistem pemerintahan, merupakan ketidakberjalanan dan ketidakefektifan seluruh komponen dalam sistem pemerintahan. Unsur pengawasan di daerah menjadi mandul, jika pelaku korupsi adalah para atasan sendiri. Keterbatasan jangkauan unsur pengawasan di daerah, menyebabkan korupsi di daerah baru dapat diketahui setelah melewati waktu 
tertentu, itupun oleh jajaran pengawasan dari Pusat. Lemahnya pengawasan Pusat dan keterbatasan jumlah sumber daya manusia pada penyidik KPK, juga merupakan faktor yang menghambat pemberantasan korupsi. Oleh karena itu dibutuhkan kerjasama dan bantuan baik dari Kepolisian, Kejaksaan maupun BPKP merupakan kendala serius yang selalu menghambat kecepatan penyidikan dan penentuan dari KPK.

Optimalisasi pemberantasan korupsi perlu dilakukan dengan mengoptimalkan pelaksanaan pengawasan dalam Undang-Undang Nomor 6 Tahun 2014 tentang Desa ${ }^{35}$, Undang-Undang No 23 Tahun 2014 Tentang Pemerintahan Daerah ${ }^{36}$, Peraturan Pemerintah Pengganti UndangUndang Nomor 1 Tahun 2014 Tentang Pemilihan Gubernur, Bupati, dan Walikota ${ }^{37}$ sehingga dapat secara efektif untuk mencegah terjadinya korupsi. Dengan demikian penegakan hukum merupakan langkah terakhir dan merupakan antisipasi maksimal termasuk harus melakukan strategi represif.

\section{DAFTAR PUSTAKA}

\section{Buku}

Alatas Syed, Hussein, Korupsi Sebab Sifat dan Fungsi, (Jakarta LP3ES, 1987).

Simanjuntak, A. Robert et all, Pasang Surut Otonomi Daerah Sketsa Perjalanan 100 Tahun, (Jakarta TIFA \& Institute In Local Development, 2005).

Benveriste, Guy, Birokrasi, Terjemahan Sahat Simamora, (Jakarta CV Rajawali, 1989).

Damanhuri, Dindin S., Korupsi, Reformasi Birokrasi dan Masa Depan Ekonomi Indonesia, (Jakarta
Lembaga Fakultas Ekonomi Universitas Indonesia, 2006)

Kurniawan, Luthfi J. et all, Peta Korupsi di Daerah, (Malang Corruption Watch (MCW) dan Yapika Jakarta, 2006).

Marijan, Kacung, Sistem Politik Indonesia, Konsolidasi Demokrasi Pasca Orde Baru, (Jakarta Kencana Prenada Media Group, 2010).

Nitibaskara, Tb Ronny Rahman, Perangkap Penyimpangan dan Kejahatan, (Jakarta YPKIK, 2009).

Nurdjana, IGM, Sistim Hukum Pidana dan Bahaya Laten Korupsi Perspektif Tegaknya Keadilan Melawan Hukum Pidana, (Yogyakarta Pustaka Pelajar, 2010).

Nuralam, Kesejahteraan Yang Tersandera Implementasi Desentralisasi Fiskal dan Otonomi Khusus di Papua (Yogyakarta, Sarjana, 2011).

Prasodjo, Eko, Reformasi Kedua Melanjutkan Estafet Reformasi, (Jakarta Salemba Humanika, 2009).

Ratnawati, Tri, Pemekaran Daerah, Politik Lokal \& Beberapa Isu Terseleksi, (Yogyakarta Pustaka Pelajar, 2009).

Soekanto, Soeryono, Kesadaran Hukum dan Kepatuhan Hukum, (Jakarta Rajawali Pers, 1982).

Salossa, Jacobus Perviddya, Otonomi Khusus Papua Mengangkat Martabat Rakyat Papua Di Dalam NKRI, (Jakarta Sinar Harapan, 2006).

Suseno, Frans Magnis, Etika Politik Prinsip-prinsip Moral Dasar Kenegaraan Moderen, (Jakarta PT Gramedia, 1991),

Sadjijono, Fungsi Kepolisian Dalam Pelaksanaan Good Governance, (Yogyakarta Laksbang, 2010).

\section{Makalah / Artikel / Prosiding / Hasil Penelitian}

Forum Keadilan, "Agung Podomoro dan Bupati Karawang", Nomor 14 Tahun XXIII/11-17 Agustus 2014.

Forum Keadilan, "Akil Difonis, KPK Bidik 15 Kepala Daerah," Nomor 11 Tahun XXIII/07-13 Juli 2014.

Forum Keadilan, "Dua Cari Kuasa, Tiga Harus Kuasa”, Nomor 43/25 Februari - 03 Maret 2013. 
Forum Keadilan, "Lolos di Lahan Kuburan Terjerat di Hutan", Nomor 03 Tahun XXIII/12-18 Mei 2014.

Forum Keadilan, "Pundi-Pundi Keluarga Rina Berisi Uang Haram", Nomor 16 Tahun XXIII/25-31 Agustus 2014.

Kompas, "Kerja Keras Jangan Berhenti di Pilpres", Sabtu 23 Agustus 2014

Kompas, "Tren Korupsi naik Lagi", Senin 18 Agustus 2014

Pradja, Adnan Pandu, "KPK dan Jokowi-JK", Kompas, Selasa 26 Agustus 2014.

\section{Peraturan:}

Undang-undang Nomor 22 Tahun 1999 Tentang Pemerintahan Daerah.

Undang-Undang Nomor 25 Tahun 1999 Tentang Perimbangan Keuangan Antara Pemerintah Pusat dan Daerah.

Undang-undang Nomor 31 Tahun 1999 Tentang Pemberantasan Tindak Pidana Korupsi.

Undang-undang Nomor 20 Tahun 2001 Tentang Pemberantasan Tindak Pidana Korupsi.
Undang-Undang Nomor 30 Tahun 2002 Tentang Komisi Pemberantasan Korupsi.

Undang-undang Nomor 32 Tahun 2004 Tentang Pemerintahan Daerah.

Undang-Undang Nomor33 Tahun 2004 Tentang Perimbangan Keuangan Antar Pemerintah Pusat dan Daerah.

Undang-undang Nomor 2 Tahun 2002 Tentang Kepolisian negara Republik Indonesia.

Undang-Undang Nomor 16 Tahun 2004 Tentang Kejaksaan Republik Indonesia.

Undang-Undang Nomor 8 Tahun 2010 Tentang Tindak Pidana Pencucian Uang.

Undang-Undang Nomor 6 Tahun 2014 tentang Desa.

Undang-Undang Nomor 23 Tahun 2014 Tentang Pemerintahan Daerah

Peraturan Pemerintahan Pengganti UndangUndang Nomor 1 Tahun 2014 Tentang Pemilihan Gubernur, Bupati, dan Walikota 